\title{
Physical-chemical, nutritional and antioxidant properties of tucumã (Astrocaryum huaimi Mart.) fruits
}

\section{Caracterização físico-química, nutricional e antioxidante de frutos de tucumã (Astrocaryum huaimi Mart.)}

\author{
Mirelly Marques Romeiro Santos ${ }^{1}$; Dayane Stéphanie Fernandes ${ }^{2}$; Camila Jordão \\ Cândido ${ }^{3}$; Leandro Fontoura Cavalheiro ${ }^{4}$; Anderson Fernandes da Silva ${ }^{5}$; Valter \\ Aragão do Nascimento ${ }^{6}$; Manoel Mendes Ramos Filho ${ }^{7}$; Elisvânia Freitas dos \\ Santos $^{8 *}$; Priscila Aiko Hiane ${ }^{8}$
}

\begin{abstract}
The Brazilian Cerrado contains a large number of fruit species whose nutritional and physical-chemical properties have not been fully characterized to date. The fruit of tucumã (Astrocaryum huaimi Mart) is ellipsoid with fibrous and gelatinous pulp, unique odor, and has significant economic importance in the region. The objective of this study is to analyze the physical-chemical, nutritional, and antioxidant properties of the fruit of tucumã grown in Minas Gerais state, Brazil. Water content, ashes, proteins, lipids, carbohydrates, total dietary fiber, $\mathrm{pH}$, titratable acidity, soluble solids, vitamin $\mathrm{C}$, minerals, and fatty acids were analyzed. Total phenols, tannins, and antioxidant activity were analyzed using the Folin-Ciocalteau method, Folin-Denis method, and photocolorimetric method of the stable free radical DPPH, respectively, in aqueous, acetone, and ethanol extracts. The most relevant components in the fruit were lipids, fibers, vitamin $\mathrm{C}$, unsaturated fatty acids, iron, potassium, manganese, and bioactive compounds. The analysis of the bioactive compounds revealed that the fruit has high antioxidant activity. The acetone extract presented the highest antioxidant capacity followed by the ethanol and aqueous extracts. The results indicated that the tucumã fruit has high nutritional value as a source of lipids, fibers, calories, vitamin C, minerals, and unsaturated fatty acids, and high antioxidant activity. Therefore, consuming the tucumã fruit pulp may help prevent nutritional deficiencies and chronic noncommunicable diseases.
\end{abstract}

Key words: Functional food products. Cerrado. Fruit.

\footnotetext{
${ }^{1}$ Discente de Doutorado, Programa de Pós-Graduação em Saúde e Desenvolvimento na Região Centro-Oeste, Universidade Federal de Mato Grosso do Sul, UFMS, Campo Grande, MS, Brasil. E-mail: mirellymarques@hotmail.com

2 Discente de Mestrado, Programa de Pós-Graduação em Saúde e Desenvolvimento na Região Centro-Oeste, UFMS, Campo Grande, MS, Brasil. E-mail: daystephaniefernandes@gmail.com

3 Pesquisadora, Faculdade de Ciências Farmacêuticas, Alimentos e Nutrição, UFMS, Campo Grande, MS, Brasil. E-mail: cahjordao@gmail.com

4 Pesquisador, Instituto de Química, UFMS, Campo Grande, MS, Brasil. E-mail: lernfe@gmail.com

5 Pesquisador, Laboratório de Metabolismo Mineral e Biomateriais, Faculdade de Medicina, Programa de Pós-Graduação em Saúde e Desenvolvimento na Região Centro-Oeste, UFMS, Campo Grande, MS, Brasil. E-mail: alemao fer@hotmail.com

6 Prof. Laboratório de Metabolismo Mineral e Biomateriais, Faculdade de Medicina, Programa de Pós-Graduação em Saúde e Desenvolvimento na Região Centro-Oeste, UFMS, Campo Grande, MS, Brasil. E-mail: aragao60@hotmail.com

7 Prof., Faculdade de Ciências Farmacêuticas, Alimentos e Nutrição, UFMS, Campo Grande, MS, Brasil. E-mail: manoel.filho@ ufms.br

8 Prof ${ }^{\text {as }}$, Faculdade de Ciências Farmacêuticas, Alimentos e Nutrição, Programa de Pós-Graduação em Saúde e Desenvolvimento na Região Centro-Oeste, UFMS, MS, Brasil. E-mail: elisvania@gmail.com; priscila.hiane@ufms.br

Author for correspondence
} 


\section{Resumo}

O Cerrado Brasileiro é responsável por uma ampla riqueza de espécies frutíferas que ainda não foram estudadas em relação às suas características nutricionais e físico-químicas. O tucumã é um fruto elipsoide de polpa fibrosa, consistência pastosa e odor característico, representando uma importante atividade econômica regional. $\mathrm{O}$ objetivo deste estudo foi analisar as propriedades físico-químicas, nutricionais e antioxidantes do fruto tucumã (Astrocaryum huaimi Mart) do Estado de Minas Gerais. Foram realizadas análises físicas, umidade, cinzas, proteínas, lipídios, carboidratos, fibra alimentar total, $\mathrm{pH}$, acidez titulável, sólidos solúveis, vitamina $\mathrm{C}$, minerais e ácidos graxos. Fenóis totais, taninos e a atividade antioxidante foram analisados pelo método Folin-Ciocalteau, Folin-Denis e pelo método fotocolorimétrico do radical livre estável DPPH, respectivamente, em três extratos: aquoso, acetônico e etanólico. Os constituintes que se destacaram no fruto foram lipídios, fibras, vitamina $\mathrm{C}$, ácidos graxos insaturados, ferro, potássio, manganês e compostos bioativos. Em relação aos compostos bioativos analisados foi possível verificar o elevado potencial antioxidante desse fruto. Dentre os extratos analisados, o acetônico foi o que apresentou a maior capacidade antioxidante seguido do etanólico e do aquoso. Os resultados indicaram que o fruto de tucumã apresenta importantes propriedades nutricionais, como fonte de lipídios, fibras, calorias, vitamina $\mathrm{C}$, minerais, ácidos graxos insaturados, bem como elevado potencial antioxidante. O consumo de polpa de tucumã poderá contribuir para prevenir carências nutricionais e também na prevenção de doenças crônicas não transmissíveis.

Palavras-chave: Alimento funcional. Cerrado. Fruto.

\section{Introduction}

The Brazilian Cerrado has the highest biodiversity of all savanna biomes worldwide, with 7,000 species, of which many are endemic (KLINK; MACHADO, 2005). Native populations may benefit from the high diversity of local fruits, market them as in natura or processed foods, and include them in the diet to increase the nutritional status and reduce food insecurity (HAMACEK et al., 2013).

The tucumã belongs to the family Arecaceae (palm trees), genus Astrocaryum, and is popularly known as "tucumanzeiro" (CARDOSO et al., 2013). This species is more common in the Amazon region but is also found in other regions. The fruit has an ellipsoid shape with a length of 3 to $5 \mathrm{~cm}$, thickness of 2 to $4 \mathrm{~mm}$, yellow-orange color when ripe, fibrous and gelatinous pulp, and characteristic odor (FERREIRA et al., 2008). It is widely used by the Amazon peoples, who consume almost all parts of the palm tree. The mesocarp (pulp) is highly appreciated by the local population and is used for producing ice creams, popsicles, and tapioca and sandwich fillings. The pulp is also used as feed for cattle, pigs, fish, and chickens, and for producing soap (SHANLEY, 2005). The tucumã is classified as a product of extractivism of medium importance and has significant economic importance in the region (MOUSSA; KAHN, 1997).

Therefore, searching for new food sources that are rich in bioactive compounds, such as antioxidants in phenolic compounds and tannins, is essential. Brazil has a rich biodiversity, and it is possible to study several fruits and determine their unique properties. The study of antioxidants is vital because many chronic non-communicable diseases are associated with an imbalance in the production of free radicals and antioxidants (ZIMMERMANN; KIRSTEN, 2008). The higher consumption of fruits and vegetables is associated with a decrease in the rate of chronic non-communicable diseases because these foods have high antioxidant activity (COSTA et al., 2013; SANTOS et al., 2014).

The objective of this study is to analyze the physical-chemical, nutritional, and antioxidant properties of the fruits of tucumã (Astrocaryum huaimi Mart) from the state of Minas Gerais, Brazil. 


\section{Material and Methods}

The fruits of tucumã (Astrocaryum huaimi Mart.) were collected at the Fazenda São Sebastião in the municipality of Limeira do Oeste, Minas Gerais state, Brazil, at the geographical coordinates $19^{\circ} 18^{\prime} 42$ "S, $50^{\circ} 43^{\prime} 25^{\prime \prime} \mathrm{W}$. The fruits were labeled and registered in the Herbarium of the Federal University of Mato Grosso do Sul (CGMS) under Registration No. 54609. The collection was performed in December 2014. One bunch of fruit was collected from each palm tree, totaling three bunches of fruits. Each bunch contained approximately 200 fruits, which were selected according to the color of the exocarp (peel) (yellow-orange), indicating they were fully ripe.

In the laboratory of the Food Technology and Public Health Unit (Unidade de Tecnologia de Alimentos e Saúde Pública-UTASP) of CCBS at the Federal University of Mato Grosso do Sul, the fruits were selected, and the deteriorated and damaged fruits were discarded. After that, the fruits were washed in running water for further analysis.

\section{Physical analyses}

The length and diameter of the whole fruit were determined using a Stainless Hardened digital caliper with a precision of $0.01 \mathrm{~mm}$. The weight of the whole fruit, exocarp (peel), mesocarp (pulp), endocarp (seed), and kernel was measured on a Shimadzu analytical scale after manual pulping (LIMA et al., 1986).

\section{Sample preparation}

Fruit pulping consisted of separating the mesocarp and exocarp using a stainless steel knife, and this material was designated raw pulp. The obtained raw pulp was dried at $45{ }^{\circ} \mathrm{C}$ in a forced air circulation oven for 2 days. The dried material was crushed roughly in a cutter $\left(\mathrm{SIRE}^{\circledR}\right)$ and later in a turrax-type homogenizer $\left(\mathrm{TECNAL}^{\circledR}\right)$. The homogenized samples were sieved in a 60-mesh sieve to achieve granulometric uniformity. After that, the samples were packaged, identified, and used for physical-chemical analyses.

\section{Physical-chemical analyses}

All physical-chemical analyses were conducted in triplicate. The evaluated parameters were water content, $\mathrm{pH}$, and titratable acidity using the methodologies of the Adolfo Lutz Institute (IAL, 2008). Proteins were determined using the MicroKjeldahl method with factor 6.25. Lipids were analyzed using the Soxhlet method according to AOAC protocols (2000). Reducing sucrose, non-reducing sucrose, and starch were quantified using the Lane-Eynon reductometric method (BRASIL, 2005). The total dietary fiber content was determined using the enzymatic method with $\alpha$-amylase $\left(\right.$ Termamyl $\left.^{\circledR}\right)$, enzymatic digestion with protease $\left(\right.$ Alcalase $^{\circledR}$ ) and amyloglucosidase $\left(\mathrm{AMG}^{\circledR}\right)$ for hydrolysis, and filtration in ethanol for extraction of fibers using the method AOAC 985.29 described by AOAC (2000). The ascorbic acid content was determined by titration with 2,6-dichlorophenolindophenol according to the AOAC method (1995). Three grams of homogenized "in natura" sample were used for quantifying soluble solids. A gauze was used to filter the solid particles, and two drops of the homogenate were placed in the prism of a digital refractometer model HI 96801 (Hanna Instruments Brazil, São Paulo, São Paulo). The value obtained by spectrophotometry was multiplied by two.

Cobalt, iron, manganese, magnesium, nickel, potassium, calcium, sodium, cadmium, copper, zinc, chromium, molybdenum, silicon, and phosphorus were quantified using inductively coupled plasma optical emission spectrometry (Thermo Fisher Scientific, Cambridge, England) model iCAP 6300 Duo (POUSSEL; MERMET, 1995). 


\section{Quantification of fatty acids}

Lipids were extracted by cold extraction using the method of Bligh and Dyer (1959). After extraction, a 100-mg aliquot of the lipid sample was transferred to a screw-capped tube, $2 \mathrm{~mL}$ of methanolic sodium hydroxide was added to the test tube, and the solution was heated in a water bath for $5 \mathrm{~min}$. After that, $6 \mathrm{~mL}$ of the esterification mixture was added to the warm solution and heated for $3 \mathrm{~min}$. After this step, $5 \mathrm{~mL}$ of distilled water was added to the tube, and the solution was agitated (HARTMAN; LAGO, 1973).

The formed methyl esters were extracted by adding $6 \mathrm{~mL}$ of hexane (three 2-mL aliquots in sequence), and the organic phase (supernatant) was transferred to another tube using a Pasteur pipette. The methyl ester solution was washed with two $5-\mathrm{mL}$ volumes of saturated sodium bicarbonate solution. The organic phase was transferred to another screw-capped tube, and the solvent was evaporated. After that, the solution was filtered and transferred to Eppendorf tubes.

The fatty acids extracted from the fruit samples were determined using a Varian gas-liquid chromatograph (model CP-3800) with a fused silica capillary column (length, $30 \mathrm{~m}$; internal diameter, $0.25 \mathrm{~mm}$; BPX-70, 70\% cyanopropyl polysilphenylsiloxane) and a flame ionization detector (DIC) with a split/splitless-type injector. The gases used in the detector were helium (carrier gas) at a flow rate of $1.0 \mathrm{~mL} / \mathrm{min}$, synthetic air, and hydrogen. Nitrogen was used as an auxiliary gas. The working temperature in the injector was 200 ${ }^{\circ} \mathrm{C}$. The temperature in the column was $80{ }^{\circ} \mathrm{C}$ for 2 min, then increased at a rate of $4{ }^{\circ} \mathrm{C}$ per min until it reached $220{ }^{\circ} \mathrm{C}$, and was maintained at $220{ }^{\circ} \mathrm{C}$ for $10 \mathrm{~min}$. The temperature of the detector was $250^{\circ} \mathrm{C}$. The peaks of the isolated fatty acid fractions were identified by comparison with the retention times of pure fatty acid methyl esters (Sigma) and quantified by area normalization. The results were expressed as percentages $(\%)$. The analyses were conducted in the Laboratory of Fuel Analysis (Laboratório de Análises de Combustíveis-LABCOM) of the Department of Chemistry of the Federal University of Mato Grosso do Sul (Universidade Federal Universidade Federal de Mato Grosso do SulUFMS).

\section{Determination of the daily value $(\% D V)$}

The $\% \mathrm{DV}$ was calculated using $40 \mathrm{~g}$ of the sample based on the values recommended for subjects of both sexes aged 19 to 50 years (INSTITUTE OF MEDICINE, 2005). The nutrients were evaluated using mean values for carbohydrates, proteins, lipids, and dietary fiber.

The $\% \mathrm{DV}$ of minerals was calculated using 40 $\mathrm{g}$ of the sample based on the recommended values for subjects of both sexes aged 19 to 50 years (FAO, 2001).

\section{Analysis of antioxidant compounds}

The bioactive compounds were analyzed using the raw pulp of fruits "in natura." The extracts were prepared according to the methodology of Roesler et al. (2007) using the aqueous, ethanol, and acetone extractions. The aqueous extraction was carried out using distilled water at a fruit:water ratio of 1:3 (m $\left.\mathrm{v}^{1}\right)$. The ethanolic extraction was performed using $95 \%$ alcohol at a fruit:alcohol ratio of 1:3 $\left(\mathrm{m} \mathrm{v}^{-1}\right)$. The acetone extraction was performed using acetone at a fruit:acetone ratio of $1: 3\left(\mathrm{~m} \mathrm{v}^{-1}\right)$. For each extraction, the material was homogenized for 20 min using a Kline stirrer. After that, the sample was filtered in gauze and re-extracted in the same solvent under the same conditions, and the filtrate was transferred to a 50-mL flask. Phenolic compounds, tannins, and antioxidant activity were determined in the extracts (BATISTA, 2013; ROESLER et al., 2007).

The antioxidant capacity for sequestering free radicals was evaluated using the photocolorimetric method of the stable free radical 1,1-diphenyl- 
2-picryl-hydrazyl (DPPH) (MELO et al., 2006; ALI et al., 2007). The method was based on the sequestration of DPPH by the antioxidants present in the samples, and absorbance was read at $517 \mathrm{~nm}$ in a spectrophotometer. Different concentrations of ethanolic solutions were prepared from the aqueous, ethanol, and acetone extracts by adding $1800 \mu \mathrm{L}$ of DPPH $\left(0.004 \% \mathrm{~m} \mathrm{v}^{-1}\right)$, and the final volume was adjusted to $2000 \mu \mathrm{L}$ with ethanol. Each sample was incubated at room temperature for $30 \mathrm{~min}$ in the dark. The ability to sequester free radicals was expressed as a percentage of inhibition of radical oxidation, calculated by the formula $\%$ inhibition $=\left(\left(A_{\text {DPPH }}-\mathbf{A}_{\text {Extr }}\right) / \mathbf{A}_{\text {DPPH }}\right) * \mathbf{1 0 0}$, where $A_{\text {DPPH }}$ was the absorbance of the DPPH solution, and $\mathrm{A}_{\text {Extr }}$ was the absorbance of the sample in solution (ROESLER et al., 2007). The results were expressed as $\mathrm{IC}_{50}$, which represents the fresh mass in grams of the sample per gram of DPPH used in the reaction (RUFINO et al., 2010).

Total phenols were quantified using the FolinCiocalteau method (SWAIN; HILLS, 1959), which involves the reduction of the reagent by the phenolic compounds present in the sample and the formation of a blue complex whose absorbance is read at 760 $\mathrm{nm}$ in a spectrophotometer. The reaction mixture contained $0.5 \mathrm{~mL}$ of the extract, $2.5 \mathrm{~mL}$ of the Folin-Ciocalteau reagent, and $2 \mathrm{~mL}$ of a saturated solution of sodium carbonate. A standard curve was constructed with gallic acid at the concentrations of $0.025,0.075,0.09$, and $0.105 \mathrm{mg} \mathrm{mL}^{-1}$. The results were expressed as $\mathrm{mg}$ of gallic acid equivalent in $100 \mathrm{~g}^{-1}$ of fresh sample using the formula $\mathbf{E A G}=$ $\left(C^{*} \mathbf{V} / \mathbf{M}\right)^{*} \mathbf{1 0 0}$, where $\mathrm{C}$ was the concentration obtained in the curve $(\mathrm{mg} / \mathrm{mL}), \mathrm{V}$ was the sample volume in the reaction $(\mathrm{mL})$, and $\mathrm{M}$ was the sample mass in the reaction $(\mathrm{g})$.

Total tannins were quantified using the FolinDennis method (BRASIL, 2005), which involved the reduction of the reagent and formation of a blue complex whose absorbance was read at 760 $\mathrm{nm}$. The reaction mixture contained $0.5 \mathrm{~mL}$ of the extract, $1.0 \mathrm{~mL}$ of the Folin-Dennis reagent, and 1 $\mathrm{mL}$ of saturated sodium carbonate solution, and the final volume of $10 \mathrm{~mL}$ was completed with distilled water. A standard curve was constructed with tannic acid. The results were expressed as mg of tannic acid equivalent in $100 \mathrm{~g}^{-1}$ fresh sample using the formula $\mathbf{E A T}=(\mathrm{C} * \mathrm{~V} / \mathrm{M}) * \mathbf{1 0 0}$, where $\mathrm{C}$ was the concentration obtained in the curve $\left(\mathrm{mg} \mathrm{mL}^{-1}\right), \mathrm{V}$ was the sample volume in the reaction $(\mathrm{mL})$, and $\mathrm{M}$ was the sample mass $(\mathrm{g})$ in the reaction.

\section{Statistical analysis}

Data were analyzed using the software Statistical Package for Social Sciences (SPSS) version 22.0 and expressed as the mean \pm standard deviation. The comparisons were performed using ANOVA followed by Tukey's post-hoc test. P-values of less than 0.05 were considered significant.

\section{Results and Discussion}

The values obtained in the physical analysis of the "in natura" samples and the comparison with literature data are shown in Table 1. 
Table 1. Physical parameters of the fruits of tucumã (Astrocaryum huaimi Mart.) from Limeira do Oeste, Minas Gerais, Brazil.

\begin{tabular}{lrcc}
\hline Parameters & Mean \pm SD & $\begin{array}{c}\text { Ferreira et al. (2008) } \\
\text { Astrocaryum vulgare Mart. }\end{array}$ & $\begin{array}{c}\text { Simões (2010) } \\
\text { Astrocaryum vulgare Mart. }\end{array}$ \\
\hline Peel weight (g) & $2.26 \pm 0.55$ & 6.75 & 6.90 \\
Pulp weight (g) & $5.37 \pm 3.52$ & 5.68 & 3.64 \\
Seed weight (g) & $8.43 \pm 3.36$ & 10.03 & 10.00 \\
Dry seed weight (g) & $6.37 \pm 1.26$ & - & - \\
Dry kernel weight (g) & $2.44 \pm 0.52$ & - & - \\
Fruit circumference (cm) & $10.08 \pm 0.62$ & - & - \\
Fruit diameter (mm) & $27.27 \pm 1.86$ & 31.23 & - \\
Mesocarp thickness (mm) & $2.88 \pm 0.43$ & - & - \\
Seed thickness (mm) & $2.95 \pm 0.75$ & - & - \\
Kernel thickness (mm) & $5.02 \pm 0.53$ & - & - \\
Exocarp thickness (mm) & $0.54 \pm 0.17$ & - & \\
\hline
\end{tabular}

SD: standard deviation.

The mean peel weight, seed weight, and fruit diameter were smaller than those obtained by Ferreira et al. (2008) and Simões (2010) for Astrocaryum vulgare Mart. The pulp weight in our study was similar to that found by Ferreira et al. (2008) but higher than that found by Simões (2010). No literature data on the other physical parameters were found. Oliveira et al. (2003) reported that differences in the physical parameters might be due to the analyzed species, climate, soil, and fruiting period, leading to different results regarding fruit size, weight, and composition.

The edible part of the tucumã fruit (pulp + dry kernel) represents $48.6 \%$ of the total weight of the fruit, thus presenting adequate composition for culinary preparations and providing nutrients (RAMOS et al., 2008).

The mean values obtained in the analysis of the physical-chemical composition of the dry raw pulp (mesocarp + exocarp) using a 100-gram sample as reference are shown in Table 2.

The mean water content of the dry raw pulp was $10.22 \%$, which differed from the study of Yuyama et al. (2008), whereby the mean water content of the dry and milled pulp of $A$. aculeatum Meyer. from
Rio Preto da Eva, Amazonas, Brazil, was 1.67\%. This difference is probably due to the intensity of the drying process applied in each study and the evaluated species. In contrast, Damasceno et al. (2008) analyzed the dry pulp of $A$. vulgare Mart. from the northeastern region of Pará and the state of Maranhão, and the water content varied from 3.47\% to $9.55 \%$, which is similar to the value obtained in our study.

The percentages of ashes, proteins, and total carbohydrates in the dry raw pulp were similar to those found by Damasceno et al. (2008) and Yuyama et al. (2008).

It is of note that tucumã fruits have high lipid content. This characteristic contributes considerably to its high energy content. The mean percentage of lipids was $18.28 \pm 0.04 \%$, which is similar to that found by Damasceno et al. (2008) (18.88 $\pm 0.03 \%)$ (13.53-50.72\%). The percentage found by Yuyama et al. (2008) was $61.60 \pm 0.62 \%$, which is higher than that of the study by Damasceno et al. (2008) and the present study. Ferreira et al. (2008) obtained a percentage of $40.49 \%$ in the in natura fruit of $A$. vulgare Mart. from the region of Mazagão, Amapá, Brazil. 
Table 2. Physical-chemical composition $\left(\mathrm{g} .100 \mathrm{~g}^{-1}\right)$ of the dry raw pulp (mesocarp + exocarp) of tucumã fruits (Astrocaryum huaimi Mart.) from Limeira do Oeste, Minas Gerais, Brazil.

\begin{tabular}{lccc}
\hline Components (g.100g-1) & Mean \pm SD & $\begin{array}{c}\text { Damasceno et al. (2008) } \\
\text { Astrocaryum vulgare } \\
\text { Mart. Dry }\end{array}$ & $\begin{array}{c}\text { Yuyama et al. (2008) } \\
\text { Astrocaryum aculeatum } \\
\text { Meyer. Dry }\end{array}$ \\
\hline Water content (\%) & $10.22 \pm 0.25$ & $3.47-9.55$ & 1.67 \\
Ashes & $3.58 \pm 0.06$ & $1.78-3.32$ & 2.4 \\
Proteins & $5.18 \pm 0.11$ & $4.35-8.81$ & 6.7 \\
Lipids & $18.28 \pm 0.04$ & $13,53-50.72$ & 61.60 \\
Total carbohydrates & $31.46 \pm 0.04$ & $33.16-71.03$ & 27.63 \\
$\quad$ Glucose & $11.24 \pm 0.00$ & ND & ND \\
Sucrose & $0.01 \pm 0.00$ & ND & ND \\
Starch & $20.21 \pm 0.04$ & ND & ND \\
Total dietary fiber & $35.95 \pm 0.01$ & ND & ND \\
$\quad$ Soluble dietary fiber & $3.29 \pm 0.01$ & ND & ND \\
$\quad$ Insoluble dietary fiber & $32.66 \pm 0.01$ & ND & ND \\
Calories (kcal.100g-1) & 311.08 & ND & \\
\hline
\end{tabular}

SD: standard deviation. ND: not determined.

Other authors observed that the lipid content of tucumã fruits varied considerably. Oliveira et al. (2013) studied A. vulgare Mart. from the Germplasm Bank of Embrapa Amazônia Oriental, and indicated that the percentage of lipids, on a dry basis, in the fruit mesocarp varied from $11.80 \%$ to $73.80 \%$. Aragão (2013) reported that the percentage of lipids in the pulp in natura was $22.94 \%$, corresponding to approximately $41.67 \%$ in dry basis, according to the water content obtained. The percentage of lipids in the mesocarp + exocarp of A. aculeatum in natura from two municipalities of the state of Amazonas varied from $33.9 \%$ to $37.5 \%$ (YUYAMA et al., 2005).

Ferreira et al. (2008) hypothesis that variations in fruit composition are because of different species analyzed, in addition to fruit heterogeneity and environmental factors such as climate, soil, growth temperature, and fruiting period. Aragão (2013), Damasceno et al. (2008), and Oliveira et al. (2013) studied A. vulgare Mart. from northeastern Pará and the state of Maranhão, whereas Yuyama et al.
(2008) studied A. aculeatum Meyer. from Rio Preto da Eva, Amazonas state.

The mean total dietary fiber of the fruits was $35.95 \%$. The percentages found by Aragão (2013), Fernandes et al. (2007), Yuyama et al. (2005) were $9.0 \%, 14.21 \%$, and $24.1-35.4 \%$, respectively. The percentage of insoluble dietary fiber was $32.66 \%$, corresponding to $90.85 \%$ of the total dietary fiber. The inclusion of fibers in the diet is advocated because of their health benefits, including improvement of intestinal transit, increase in fecal volume, delay in glucose absorption, and prevention of colon cancer (FERREIRA et al., 2008).

The physical-chemical composition of the fruit per serving (two units), with an approximate weight of $40 \mathrm{~g}$, and the recommended daily intake (RDI) expressed as $\% \mathrm{DV}$ of the raw pulp are presented in Table 3.

The mean levels of nutrients were 2,214.25 Kcal/ day of total energy, $275.5 \mathrm{~g} /$ day of carbohydrates, $82.9 \mathrm{~g} /$ day of proteins, $82.25 \mathrm{~g}$ /day of lipids, and $15.97 \mathrm{~g} /$ day of fiber, according to the RDI (2005). 
Table 3. Physical-chemical composition per serving (g.40 $\left.\mathrm{g}^{-1}\right)^{*}$ and daily recommended intake (DRI) expressed as percentage daily value $(\% \mathrm{DV})$ of the dry raw pulp (mesocarp + exocarp) of the fruits of tucumã (Astrocaryum huaimi Mart.) from Limeira do Oeste, Minas Gerais, Brazil.

\begin{tabular}{lcc}
\hline Components $\left(\mathbf{g . 4 0 \mathbf { g } ^ { - 1 }}\right)$ & Mean \pm SD & \%DV \\
\hline Moisture content & $4.09 \pm 0.25$ & -- \\
Ashes & $1.43 \pm 0.06$ & - \\
Proteins & $2.07 \pm 0.11$ & 2.49 \\
Lipids & $7.31 \pm 0.04$ & 8.88 \\
Total carbohydrates & $12.58 \pm 0.04$ & 4.57 \\
$\quad$ Glucose & $4.5 \pm 0.00$ & -- \\
$\quad$ Sucrose & $0.004 \pm 0.00$ & -- \\
$\quad$ Starch & $8.08 \pm 0.04$ & -- \\
Total dietary fiber & $14.38 \pm 0.01$ & 90.04 \\
$\quad$ Soluble dietary fiber & $1.32 \pm 0.01$ & -- \\
$\quad$ Insoluble dietary fiber & $13.06 \pm 0$. & -- \\
Calories, kcal.40g- & 124.43 & 5.62 \\
\hline
\end{tabular}

SD: standard deviation. \%DV: nutrients evaluated by the mean recommended daily intake (2005) based on a diet of 2,214.25 Kcal. *Serving approximately equivalent to two units.

These results indicate that the fruit is a good source of lipids and fibers (BRASIL, 2012), especially insoluble fibers, and can significantly improve the nutritional status of native populations. Considering that the mean RDI of lipids and fibers for adults of both sexes aged 19 to 50 years was 82.25 $\mathrm{g} /$ day and $15.97 \mathrm{~g} /$ day, respectively (INSTITUTE OF MEDICINE, 2005), the consumption of $40 \mathrm{~g}$ of raw pulp (mesocarp + exocarp) supplies $8.88 \%$ and $90.04 \%$ of the daily requirements of these two nutrients, respectively. Dietary fibers have several health benefits by increasing intestinal transit, lowering blood cholesterol, decreasing starch hydrolysis, delaying glucose absorption, and reducing the risk of colon complications (FERREIRA et al., 2008).

The $\mathrm{pH}$, soluble solids, titratable acidity, and vitamin $\mathrm{C}$ content of the tucumã fruits are shown in Table 4.

Table 4. Physical-chemical parameters analyzed in the fruits of tucumã (Astrocaryum huaimi Mart.) from Limeira do Oeste, Minas Gerais, Brazil.

\begin{tabular}{lc}
\hline Parameter & Mean \pm SD \\
\hline $\mathrm{pH}$ & $4.90 \pm 0.01$ \\
Soluble solids ( ${ }^{\circ}$ Brix) & $7.75 \pm 0.07$ \\
Titratable acidity (\%) & $0.21 \pm 0.02$ \\
Vitamin C (mg.100g-1) & $14.35 \pm 2.07$ \\
\hline
\end{tabular}

SD: standard deviation.

The mean $\mathrm{pH}$ (4.90) was lower than that found by Aragão (2013) (5.90) and Yuyama et al. (2008)
(5.71-5.89) in dry and in natura pulp, respectively, in $A$. vulgare Mart. 
The titratable acidity of the dry fruit was lower than that obtained by Aragão (2013) in in natura pulp $(0.32 \%)$ and by Yuyama et al. (2008) in dry pulp $(0.60 \%)$. The factors responsible for the quality of the fruits in the palm tree are the soil, climate, and stage of maturation. Therefore, the $\mathrm{pH}$ is a critical parameter in fruit conservation. The acidity is related to the stage of maturation such that the $\mathrm{pH}$ is decreased as the fruit matures (SILVA et al., 2009).

The soluble solids indicate the concentration of dissolved substances in the fruit juice, and the production of these solids depends on the maturation stage (SILVA et al., 2009). The amount of soluble solids ( ${ }^{\circ}$ Brix) in the fruit pulp $\left(7.75^{\circ}\right.$ Brix) was lower than that reported by Aragão (2013) $\left(10.0^{\circ}\right.$ Brix).

The levels of vitamin C (14.35 mg.100 $\mathrm{g}^{-1}$ ) (Table 4) were higher than those described by Aragão (2013) (1.34 mg.100 $\left.\mathrm{g}^{-1}\right)$ in the pulp and lower than those found by Santos et al. (2015) (19 mg.100g $\left.\mathrm{g}^{-1}\right)$ in the mesocarp and exocarp of $A$. vulgare Mart. from the Macapá region. Considering that the mean RDI of vitamin $\mathrm{C}$ for adults of both sexes aged 19 to 50 years is $82.5 \mathrm{mg} /$ day (DRI, 2005), the consumption of $40 \mathrm{~g}$ of the raw pulp provides $6.9 \%$ of the daily requirement of vitamin $\mathrm{C}$.

Vitamin $\mathrm{C}$ is unstable to light, high temperatures, and oxygen, and these factors need to be minimized for achieving a reliable analytical result (LEE; KADER, 2000). This substance is vital for human health and is found in many fruits. Vitamin C has antioxidant activity and is involved in the production of several hormones and synthesis of connective tissue; its antioxidant activity depends on $\mathrm{pH}$, such that the higher is the acidity, the higher is the antioxidant activity (SILVA et al., 2009).

The minerals found in the dry raw pulp of the tucumã fruit are shown in Table 5.

Table 5. Mineral composition (mg. $\left.100 \mathrm{~g}^{-1}\right)$ per serving $\left(\mathrm{mg}_{4} 40 \mathrm{~g}^{-1}\right)$ and recommended daily intake (RDI) per serving (40 g, corresponding to 2 units) of dry pulp (mesocarp + exocarp) of the fruits of tucumã (Astrocaryum huaimi Mart.) from Limeira do Oeste, Minas Gerais, Brazil.

\begin{tabular}{lcccc}
\hline Minerals & $\begin{array}{c}\text { Mean } \pm \mathbf{S D} \\
\mathbf{m g . 1 0 0 g}^{-1}\end{array}$ & $\begin{array}{c}\text { Serving } \\
\mathbf{m g . 4 0}^{-1}\end{array}$ & \%DV & RDA** \\
\hline Calcium & $162.84 \pm 3.88$ & 65.14 & $6.51 \%$ & $1000 \mathrm{mg} / \mathrm{day}$ \\
Cadmium & $0.003 \pm 0.0004$ & 0.0012 & $\mathrm{ND}$ & $\mathrm{ND}$ \\
Cobalt & $0.0091 \pm 0.001$ & 0.0036 & $\mathrm{ND}$ & $\mathrm{ND}$ \\
Copper & $0.50 \pm 0.03$ & 0.20 & 0.022 & $900 \mathrm{mg} / \mathrm{day}$ \\
Chrome & $0.25 \pm 0.05$ & 0.10 & $0.33 \%$ & $30 \mu \mathrm{g} / \mathrm{day} *$ \\
Iron & $5.15 \pm 0.59$ & 2.06 & $15.85 \%$ & $13 \mathrm{mg} / \mathrm{day}$ \\
Phosphorus & $67.33 \pm 5.55$ & 26.93 & $3.85 \%$ & $700 \mathrm{mg} / \mathrm{day}$ \\
Magnesium & $89.42 \pm 1.35$ & 35.77 & $9.9 \%$ & $362.5 \mathrm{mg} / \mathrm{day}$ \\
Manganese & $5.49 \pm 0.26$ & 2.20 & $107.34 \%$ & $2.05 \mathrm{mg} /$ day* \\
Molybdenum & $0.70 \pm 0.05$ & 0.28 & $0.62 \%$ & $45 \mu \mathrm{g} / \mathrm{day}$ \\
Nickel & $0.40 \pm 0.09$ & 0.16 & $\mathrm{ND}$ & $\mathrm{ND}$ \\
Potassium & $1,776.05 \pm 38.93$ & 710.42 & $15.11 \%$ & $4,700 \mathrm{mg} / \mathrm{day} *$ \\
Silicon & $28.25 \pm 1.95$ & 11.30 & $\mathrm{ND}$ & $\mathrm{ND}$ \\
Sodium & $14.87 \pm 0.21$ & 5.95 & $0.40 \%$ & $1,500 \mathrm{mg} / \mathrm{day} *$ \\
Zinc & $0.99 \pm 0.04$ & 0.40 & $4.21 \%$ & $9.5 \mathrm{mg} /$ day \\
\hline
\end{tabular}

SD: standard deviation; \%DV: nutrients evaluated as the mean recommended daily allowance (RDA); **Mean values recommended for subjects of both sexes aged 19 to 50 years; NA: not available; * Mean recommended values according to AI. 
Iron, manganese, and potassium were the most abundant. The amount of the other analyzed minerals was not significant but might contribute to the nutritional value of the fruit when used for supplementing the diet.

The RDI for a healthy individual of both sexes is $13 \mathrm{mg} /$ day for iron, $2.05 \mathrm{mg} /$ day for manganese, and 4,700 mg/day for potassium. Therefore, consuming one serving of pulp corresponding to two units of the fruit provides $15.85 \%, 107.34 \%$, and $15.11 \%$ of the RDI for iron, manganese, and potassium, respectively. Simões (2010) evaluated minerals in the fruit flour of $A$. vulgare Mart.) and the obtained values were lower than those of this study $(4.3 \mathrm{mg}$ of iron/100g and 1,100 $\mathrm{mg}$ of potassium/100g).

The level of manganese was higher than the RDI for this nutrient for men and women aged 19 to 50 years. However, this level does not pose a health risk because it is lower than the maximum tolerable limit (10 mg/day, mean value for both sexes) and, for this reason, the inclusion of this fruit in the diet is recommended.
The Ministerial Order No. 31/1998 of the Health Surveillance Secretariat (BRASIL, 1998), which establishes requirements for classifying solid foods as having a low mineral content $(15 \%)$ or high mineral content $(30 \%)$, determined that the dry pulp of the tucumã fruit could be classified as a source of iron and potassium and a reliable source of manganese for healthy subjects of both sexes aged 19 to 50 years.

Iron is an essential micronutrient and contributes to cognitive performance, immune status, overall metabolism, and production of hormones, including thyroid hormones. Its deficiency has adverse effects, especially anemia, which is a serious public health problem (WHO, 2001).

Potassium plays a vital role in muscle contraction, regulation of the cardiac rhythm, conduction of nerve impulses, and maintenance of the electrolyte balance. Potassium is also crucial for preventing and treating arterial hypertension (PEREIRA, 2005).

The composition of the fatty acids in the tucumã fruit is shown in Table 6.

Table 6. Fatty acid profile of the fruits of tucumã (Astrocaryum huaimi Mart.) from Limeira do Oeste, Minas Gerais, Brazil, compared to literature data.

\begin{tabular}{lcccc}
\hline Fatty acid & Structure & $\begin{array}{c}\text { Fatty } \\
\text { acid (\%) }\end{array}$ & $\begin{array}{c}\text { Ferreira et al. (2008) } \\
\text { Astrocaryum vulgare Mart. }\end{array}$ & $\begin{array}{c}\text { Simões (2010) Astrocaryum } \\
\text { vulgare Mart. }\end{array}$ \\
\hline Saturated & & & & \\
Butyric acid & C4:0 & 2.39 & ND & ND \\
Caproic acid & C6:0 & 0.69 & ND & ND \\
Lauric acid & C12:0 & 0.05 & ND & 0.03 \\
Myristic acid & C14:0 & 0.14 & ND & 0.09 \\
Pentadecylic acid & C15:0 & 0.05 & ND & 0.02 \\
Palmitic acid & C16:0 & 25.46 & 22.90 & 25.94 \\
Margaric acid & C17:0 & 0.16 & ND & 0.12 \\
Stearic acid & C18:0 & 0.14 & 2.95 & 2.67 \\
Arachidic acid & C20:0 & 0.11 & ND & 0.14 \\
Behenic acid & C22:0 & 0.07 & ND & 0.03 \\
Tricosanoic acid & C23:0 & 0.05 & ND & ND \\
Lignoceric acid & C24:0 & 0.09 & ND & 0.04 \\
Total saturated fatty acids & & 29.40 & &
\end{tabular}


continuation

\section{Unsaturated fatty acids}

Heptadecenoic acid

$\begin{array}{llll}\text { C17:1 } & 0.04 & \text { ND } & 0.07\end{array}$

Oleic acid

$\mathrm{C} 18: \ln 9 \mathrm{c} \quad 45.28$

67.62

63.47

Linolelaidic acid

$\mathrm{C} 18: 2 \mathrm{n} 6 \mathrm{t} \quad 0.47$

Linoleic acid

$\mathrm{C} 18: 2 \mathrm{n} 6 \mathrm{c}$

10.71

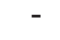

Linolenic acid

$\mathrm{C} 18: 3 \mathrm{n} 3$

1.85

1.15

1.2

$\mathrm{C} 20: \ln 9 \quad 0.37$

ND

3.14

Eicosenoic acid

$\mathrm{C} 20: 2 \mathrm{n} 6$

ND

0.27

11,14-eicosadienoic acid

C22:1n 9

0.04

ND

Erucic acid

0.10

ND

Total unsaturated fatty acids

58.86

NI

11.74

NI: not identified. ND: not determined.

The nutritional composition was 29.4 of saturated fatty acids, and the major component was palmitic acid $(25.46 \%)$. The most abundant unsaturated fatty acids were oleic acid, monounsaturated omega 9, linoleic acid, and polyunsaturated omega 6 , and these substances accounted for $95.12 \%$ of all the unsaturated fatty acids. These results corroborate those found by Ferreira et al. (2008), Morais and Gutjahr (2012), and Simões (2010), confirming that oleic acid is the most abundant unsaturated fatty acid in the tucumã fruit. Therefore, determining the fatty acid profile of food products is fundamental for better characterizing these products and possible adverse effects. Healthy fats are essential sources of unsaturated fatty acids, which protect against cardiovascular diseases and are suitable for consumption (SANTOS et al., 2013).

The levels of tannins, total phenols, and the antioxidant activity of the raw pulp "in natura" of the tucumã fruit are shown in Table 7.

Table 7. Tannins, total phenols, and antioxidant activity in the aqueous, acetone, and ethanol extracts of raw pulp "in natura" of the fruits of tucumã (Astrocaryum huaimi Mart.) from Limeira do Oeste, Minas Gerais, Brazil.

\begin{tabular}{|c|c|c|c|}
\hline Extracts & $\begin{array}{c}\text { Tannins } \\
\left(\mathrm{mg} \mathrm{EAT.100g}^{-1}\right)^{1} \\
\end{array}$ & $\begin{array}{c}\text { Total phenols } \\
\left(\mathrm{mg} \mathrm{EAG.100g}^{-1}\right)^{2}\end{array}$ & $\begin{array}{c}\text { Antioxidant activity } \\
\left(\mathrm{IC}_{50}\right)^{3}\end{array}$ \\
\hline Aqueous & $31.10 \pm 0.34^{\mathrm{c}}$ & $62.17 \pm 0.96^{c}$ & $259.95 \pm 0.75^{\mathrm{a}}$ \\
\hline Acetone extract & $90.77 \pm 1.13^{\mathrm{a}}$ & $87.80 \pm 2.48^{b}$ & $115.76 \pm 5.67^{\mathrm{c}}$ \\
\hline Ethanol extract & $63.57 \pm 1.52^{\mathrm{b}}$ & $101.78 \pm 1.88^{\mathrm{a}}$ & $138.49 \pm 0.89^{b}$ \\
\hline p-value & $<0.0001$ & $<0.0001$ & $<0.0001$ \\
\hline
\end{tabular}

${ }^{1} \mathrm{mgEAT} .100 \mathrm{~g}^{-1}=\mathrm{mg}$ of tannic acid equivalent per $100 \mathrm{~g}$ of sample. ${ }^{2} \mathrm{mgEAG} .100 \mathrm{~g}^{-1}=\mathrm{mg}$ of gallic acid equivalent per $100 \mathrm{~g}$ sample. ${ }^{3} \mathrm{IC}_{50}=\mathrm{g}$ of sample per $\mathrm{g}$ of $\mathrm{DPPH}^{-1}$ used in the reaction. Values (mean $\pm \mathrm{SD}$ ) in the same column followed by different letters were different using Tukey's test $(\mathrm{p}<0.05)$. 
There was a significant variability $(\mathrm{p}<0.0001)$ in the concentration of bioactive compounds in the analyzed extracts. The level of tannins in the acetone extract was $90.77 \pm 1.13 \mathrm{mg}$ EAT.100g ${ }^{-1}$ and was higher than that present in the ethanol and aqueous extracts. Phenolic compounds were more abundant in the ethanol extract $(101.78 \pm 1.88$ mg EAG. $\left.100 \mathrm{~g}^{-1}\right)$ than in the acetone and aqueous extracts. The aqueous extract presented the lowest antioxidant capacity $\left(\mathrm{IC}_{50}=259.95 \pm 0.75\right)$ followed by the ethanol and acetone extracts.

The extraction of phenolic compounds in natural products is affected by the solvent used in the extraction such that the higher is the polarity of the extract, the higher is the extraction yield (GAMÉZ-MEZA et al., 1999). Therefore, polarity was higher in the extracts with higher extraction yield. The extraction of antioxidants is different in each extract because of the need for higher or lower concentrations of the antioxidants to reduce the activity of free radicals (ROCHA et al., 2013).

Santos et al. (2015) evaluated the antioxidant activity in the mesocarp and endocarp of $A$. vulgare Mart. using several methods, including the DPPH method, as was also the case in the present study. The antioxidant activity in the tucumã fruit was high $\left(\mathrm{IC}_{50}=3,343\right)$ but lower than that found in this study. Santos et al. (2015) found that the fruit extracts with high antioxidant activity contained higher levels of polyphenols. The same result was observed in the present study, indicating a relationship between polyphenols and the antioxidant activity.

The levels of total phenols in the three extracts were higher than those found by Aragão (2013) in the buffered pulp extract of tucumã fruit at $\mathrm{pH}$ 7.0 (59.60 mg EAG.100g $\mathrm{g}^{-1}$ ). Santos et al. (2015) analyzed polyphenols in the mesocarp and endocarp of fruits of $A$. vulgare Mart. and the obtained values were $159 \mathrm{mg} \mathrm{GAE} 100 \mathrm{~g}^{-1}$ in the combined methanol and acetone extract, and this level was higher than that of this study.

Plants subjected to stress conditions, including pathogens and lack of nutrients, increase the production and storage of phenolic compounds because these compounds help protect the plant against external factors (IGNAT et al., 2011; CARVALHO et al., 2009).

The results of the physical-chemical analysis indicated that the consumption of pulp of the tucumã fruit should be promoted because of the high levels of macronutrients and micronutrients, favorable fatty acid composition, and high levels of bioactive compounds, and therefore this product may help prevent nutritional deficiencies and chronic diseases and promote additional health benefits. However, additional studies on this fruit are necessary because, to the best of our knowledge, no studies to date evaluated the macronutrients, micronutrients, antioxidants, total phenols, and tannins in the fruits of A. huaimi Mart.

\section{Conclusion}

Our results indicate that including tucumã fruits in the diet may help increase the intake of lipids, fibers, calories, vitamin $\mathrm{C}$, minerals, unsaturated fatty acids, and bioactive compounds.

This fruit has high levels of vitamin C. Iron, potassium, and manganese were the most abundant minerals, and the fruit was classified as a source of iron and potassium and as a rich source of manganese, suggesting the possibility of consuming whole or fractionated fruits to supplement minerals.

The analysis of the fatty acid profile indicated the predominance of unsaturated fatty acids. The analysis of bioactive compounds revealed that the acetone extract, followed by the ethanol extract, presented the highest antioxidant capacity and the highest level of phenolic compounds and tannins.

\section{Acknowledgments}

Foundation for Support to the Development of Education, Science, and Technology of the State 
of Mato Grosso do Sul (Fundação de Apoio ao Desenvolvimento do Ensino, Ciência e Tecnologia do Estado de Mato Grosso do Sul-FUNDECT) and the Federal University of Mato Grosso do Sul (Universidade Federal de Mato Grosso do SulUFMS).

\section{References}

ALI, S. S.; KASOJU, N.; LUTHRA, A.; SINGH, A.; SHARANABASAVA, H.; SAHU, A.; BORA, U. Indian medicinal herbs as sources of antioxidants. Food Research International, Toronto, v. 41, n. 1, p. 1-15, 2007.

ARAGÃO, A. B. Caracterização bioquímica e centesimal das espécies Astrocaryum vulgare Mart. (tucumã) e Endopleura uchi (Huber) Cuatrec. (uxi) nativas da região amazônica. 2013. Dissertação (Mestrado em Biotecnologia) - Instituto de Química, Universidade Estadual Paulista, Araraquara.

ASSOCIATION OF OFFICIAL ANALYTICAL CHEMISTS - AOAC. Official methods of analysis. $16^{\text {th }}$ ed. Washington: AOAC, 1995.

Oficial methods of analysis. Chapter Cereal Foods. Gaithersburg, Maryland, USA: AOAC, 2000. v. $32,5 \mathrm{p}$.

BATISTA, L. C. L. Qualidade nutricional e atividade antioxidante de laranjinha de pacu Pouteria glomerata (Miq.) Radlk) do Cerrado e do Pantanal. 2013. Dissertação (Mestrado em Saúde e Desenvolvimento na Região Centro-Oeste) - Universidade Federal de Mato Grosso do Sul, Campo Grande.

BLIGH, E. G.; DYER, W. J. A rapid method of total lipid extraction and purification. Canadian Journal Biochemistry Physiology, Otawa, v. 37, n. 8, p. 911-917, 1959 .

BRASIL. Ministério da Saúde. Agência Nacional de Vigilância Sanitária. Métodos físico-químicos para análises de alimentos. Brasília: Ministério da Saúde, 2005. 1018 p.

Ministério da Saúde. Secretaria de Vigilância Sanitária. Portaria n. 31, de 13 de janeiro de 1998. Regulamento técnico para fixação de identidade e qualidade de alimentos adicionados de nutrientes essenciais. Diário Oficial [da] República Federativa do Brasil, Brasília, 16 jan. 1998. Seção I-E, p. 4.

Ministério da Saúde. Secretaria de Vigilância Sanitária. Resolução n.54, de 12 de novembro de 2012.
Regulamento técnico sobre informação nutricional complementar. Diário Oficial [da] República Federativa do Brasil, Brasília, 12 nov. 2012.

CARDOSO, T. N.; ABREU, L. F.; FERNANDES, A. C.; MACEDO, P. C. F. Determinação de carotenoides em frutos de Tucumã (Astrocaryum vulgare Mart). In: SEMINÁRIO DE INICIAÇÃO CIENTÍFICA E SEMINÁRIO DE PÓS-GRADUAÇÃO DA EMBRAPA AMAZÔNIA ORIENTAL, 17., 1., 2013, Belém. Anais... Belém, PA: Embrapa Amazônia Oriental, 2013. p. 1-4.

CARVALHO, F. M. V.; MARCO JÚNIOR, P. de.; FERREIRA, L. G. The Cerrado into pieces: habitat fragmentation as a function of landscape use in the savannas of central Brazil. Biological Conservation, Essex, v. 142, n. 7, p. 1392-1403, 2009.

COSTA, A. G. V.; GARCIA-DIAZ, D. F.; JIMENEZ, P.; SILVA, P. I. Bioactive compounds and health benefits of exotic tropical red-black berries. Journal of Functional Foods, Amsterdam, v. 5, n. 1, p. 539-549, 2013.

DAMASCENO, F. S.; BATISTA, R. S. M.; OLIVEIRA, C. F.; ABREU, L. F.; OLIVEIRA, M. S. P. Caracterização físico-química da polpa de tucumãs do BAG da Embrapa Amazônia Oriental (Astrocaryum vulgare Mart). In: ENCONTRO NACIONAL SOBRE METODOLOGIAS DE LABORATÓRIO, 13., 2008, Belém. Anais... Belém: Embrapa Amazônia Oriental, 2008. p. 121-123.

FERNANDES, H. R.; SILVA, J. S.; PINA, D. M. M.; ROSÁRIO, L. P. C.; COSTA, R. G.; SOUSA, E. M. P.; RODRIGUES-FILHO, J. M.; OLIVEIRA, M. S. P.; PARACAMPO, N. E. N. P.; ABREU, L. F. Caracterização da polpa e do óleo de frutos da palmeira tucumã (Astrocaryum vulgare mart). In: SIMPÓSIO LATINO AMERICANO DE CIÊNCIA DE ALIMENTOS, 7., 2007, Campinas. Anais... Campinas: EMBRAPA Amazônia Oriental, 2007. 1 p.

FERREIRA, E. S.; LUCIEN, V. G.; AMARAL, A. S.; SILVEIRA, C. S. Caracterização físico-química do fruto e do óleo extraído do Tucumã (Astrocaryum vulgare mart). Alimentação e Nutrição, Araraquara, v. 19, n. 4, p. 427-433, 2008.

FOOD AND AGRICULTURE ORGANIZATION OF THE UNITED NATIONS - FAO. Human vitamin and mineral requirements. Report $7^{\mathrm{a}}$ Joint FAO/OMS Expert Consultation Bangkok. Rome: FAO, 2001.

GAMÉZ-MEZA, N.; NORIEGA-RODRIGUEZ, J. A.; MEDINA-JUAREZ, L.; ORTEGA-GARCIA, J.; CÁZAREZ-CASANOVA, R.; ÂNGULO-GUERRENO, O. Antioxidant activity in soybean oil of extracts from Thompson grape bagasse. Journal of the American Oil Chemists'Society, v. 76, n. 12, p. 1445- 1447, 1999. 
HAMACEK, F. R.; MOREIRA, A. V. B.; MARTINO, H. S. D.; RIBEIRO, S. M. R.; PINHEIRO-SANT'ANA, H. M. Valor nutricional, caracterização física e físicoquímica de jenipapo (Genipa americana L.) do cerrado de Minas Gerias. Brazilian Journal of Food and Nutrition, Araraquara, v. 24, n. 1, p. 73-77, 2013.

HARTMAN, L.; LAGO, R. C. A. Rapid preparation of fatty acid methyl esters from lipids. Laboratory Practice, London, v. 22, n. 1, p. 475-476, 1973.

IGNAT, I.; VOLF, I.; VALENTIN, I. P. A critical review of methods for characterization of polyphenolic compounds in fruits and vegetables. Food Chemistry, Barking, v. 126, n. 4, p. 1821-1835, 2011.

INSTITUTE OF MEDICINE. Dietary reference intakes (DRIs) for energy, carbohydrate, fiber, fat, fatty acids, cholesterol, protein, and amino acids. Washington: National Academy Press, 2005.

INSTITUTO ADOLFO LUTZ - IAL. Métodos físicos e químicos para análise de alimentos. Normas Analíticas. 5. ed. São Paulo: Instituto Adolfo Lutz, 2008.

KLINK, C. A.; MACHADO, R. B. A conservação do cerrado brasileiro. Megadiversidade, São Paulo, v. 1, n. 1, p. 147-155, 2005.

LEE, S. K.; KADER, A. A. Preharvest and postharvest factors influencing vitamin c content of horticultura crops. Postharvest Biology and Technology, New York, v. 20, n. 3, p. 207-220, 2000.

LIMA, R. R.; TRASSATO, R. C.; COELHO, V. O tucumã (Astrocaryum vulgare Mart.) principais características e potencialidade agroindustrial. Belém: EMBRAPACPATU, 1986. 27 p. (Boletim de pesquisa, 75).

MELO, E. A.; MACIEL, M. I. S.; LIMA, V. L. A. G.; LEAL, F. L. L.; CAETANO, A. C. S.; NASCIMENTO, R. J. Capacidade antioxidante de hortaliças usualmente consumidas. Ciência e Tecnologia de Alimentos, Campinas, v. 26, n. 3, p. 639-644, 2006.

MORAIS, L. R. B.; GUTJAHR, E. Química de oleaginosas, valorização da biodiversidade Amazônica. Brasília, DF: GTZ, 2012. 83 p.

MOUSSA, F.; KAHN, F. Uso y potencial económico de dos palmas, Astrocaryum aculeatum Meyer y $A$. vulgare Martius, em la Amazonía brasileña. In: RIOS, M.; PEDERSEN, H. B. (Ed.). Uso y manejo de recursos vegetables. Quito: Abya-Yala, 1997, p. 101-116.

OLIVEIRA, M. do S. P. de; ABREU, L. F.; FLORES, B. C. Seleção de tucumanzeiros (Astrocaryum vulgare Mart.) para teor de óleo no mesocarpo. In: CONGRESSO BRASILEIRO DE MELHORAMENTO DE PLANTAS, 2013, Uberlândia. Anais... Viçosa, MG: SBMP, 2013. p.
1064-1067.

OLIVEIRA, M. do S. P. de; COUTURIER, G.; BESERRA, P. Biologia da polinização da palmeira Tucumã (Astrocaryum vulgare Mart.) em Belém-Pará, Brasil. Acta Botanica Brasilica, São Paulo, v. 17, n. 3, p. 343-353, 2003.

PEREIRA, J. C. Nutrição e alimentação, parte específica, sais minerais (macro e microelementos). Boletim do Criadouro Campo das Caviúnas, Cruzeiro, v. 1, n. 18, p. 1-27, 2005.

POUSSEL, E.; MERMET, J. M. Emission spectrometers: 1995 analytical figures of merit. Applied Spectroscopy, Villeurbanne Cedex, France, v. 49, n. 10, p. 12A-18A, 1995.

RAMOS, M. I. L.; RAMOS FILHO, M. M.; HIANE, P. A.; BRAGA NETO, J. A.; SIQUEIRA, E. M. A. Qualidade nutricional da polpa de bocaiúva Acromia aculeata (Jacq.) Lodd. Ciência e Tecnologia de Alimentos, Campinas, v. 28, p. 90-94, 2008. Suplemento.

ROCHA, M. S.; FIGUEIREDO, R. W.; ARAÚJO, M. A. M.; MOREIRA-ARAÚJO, R. S. R. Caracterização físico-química e atividade antioxidante (in vitro) de frutos do cerrado piauiense. Revista Brasileira de Fruticultura, Cruz das Almas, v. 35, n. 4, p. 933-941, 2013.

ROESLER, R.; MALTA, L. G.; CARRASCO, L. C.; HOLANDA, R. B.; SOUSA, C. A. S.; PASTORE, G. M. Atividade antioxidante de frutas do cerrado. Ciência $e$ Tecnologia de Alimentos, Campinas, v. 27, n. 1, p. 53-60, 2007.

RUFINO, M. S. M.; ALVES, R. E; BRITO, E. S.; PÉREZ-JIMÉNEZ， J.; SAURA-CALIXTO, F.; MANCINI-FILHO, J. Bioactive compounds and antioxidant capacities of 18 non-traditional tropical fruits from Brazil. Food Chemistry, Barking, v. 121, n. 1, p. 996-1002, 2010.

SANTOS, A. C. A.; MARQUES, M. M. P.; SOARES, A. K. O.; FARIAS, L. M.; FERREIRA, A. K. A.; CARVALHO, M. L. Potencial antioxidante de antocianinas em fontes alimentares: revisão sistemática. Revista Interdisciplinar, Teresina, v. 7, n. 3, p. 149-156, 2014.

SANTOS, M. F. G.; ALVES, R. E.; RUÍZ-MÉNDEZ, M. $\mathrm{V}$. Minor componentes in oils obtained from Amazonian palm fruits. Grasas y Aceites, Sevilla, v. 64, n. 5, p. 531$536,2013$.

SANTOS, M. F. G.; MAMEDE, R. V. S.; RUFINO, M. S. M.; BRITO, E. D.; ALVES, R. E. Amazonian native palm fruits as sources of antioxidant bioactive compounds. Antioxidants, Switzerland, v. 4. n. 1, p. 591-602, 2015. 
SHANLEY, P. Frutiferas e plantas úteis na vida amazônica. Belém: CIFOR, Imazon, 2005.

SILVA, A. M. L.; MARTINS, B. A.; DEUS, T. N. Avaliação do teor de ácido ascórbico em frutos do cerrado durante o amadurecimento e congelamento. Estudos, Goiânia, v. 36, n. 11/12, p. 1159-1169, 2009.

SIMÕES, D. L. V. Composição nutricional e elaboração do biscoito e da barra de cereal do fruto de tucumã (Astrocaryum vulgare Mart.). 2010. Dissertação (Mestrado em Tecnologia e Segurança Alimentar) Faculdade de Ciências e Tecnologia da Universidade Nova de Lisboa, Caparica.

SWAIN, T.; HILLIS, W. E. The phenolics constituents of prumus domestica: the quantitative analysis of phenolic constituents. Journal of Food Science and Agriculture, London, v. 10, n. 1, p. 63-68, 1959.

WORLD HEALTH ORGANIZATION - WHO. Iron deficiency anemia: assessment, prevention and control a guide for programme managers. Geneva: WHO, 2001.
YUYAMA, L. K. O.; AGUIAR, J. P. L.; TEIXEIRA, A. O.; LOPES, T. M.; YUYAMA, K.; FÁVARO, D. I. T.; VASCONCELLOS, M. B. Polpa e casca de tucumã (Astrocaryum vulgare Mart.): quais os constituintes nutricionais? In: $8^{\circ}$ CONGRESSO NACIONAL DA SBAN - NUTRIÇÃO E ALIMENTAÇÃO NA ERA PÓS GENOMA, 30., 2005, São Paulo. Anais... São Paulo, SP: Nutrire: Revista Sociedade Brasileira de Alimentos e Nutrição, 2005. p. 332.

YUYAMA, L. K. O.; MAEDA, R. N.; PANTOJA, L.; AGUIAR, J. P. L.; MARINHO, H, A. Processamento e avaliação da vida de prateleira do tucumã (Astrocaryum aculeatum Meyer) desidratado e pulverizado. Ciência e Tecnologia de Alimentos, Campinas, v. 28, n. 2, p. 408412, 2008.

ZIMMERMANN, A. M.; KIRSTEN, V. R. Alimentos com função antioxidantes em doenças crônicas: uma abordagem clínica. Ciências da Saúde, Santa Maria, v. 9, n. 1, p. 51-68, 2008. 
